\title{
Urban Form and Productivity in México 1995-2015
}

\author{
Jorge Montejano ${ }^{1 *}$, Camilo Caudillo ${ }^{1}$, Paavo Monkkonen ${ }^{2}$, Erick Guerra ${ }^{3}$, \\ Juan M. Núñez ${ }^{1}$, Blanca E. Garza ${ }^{4}$, Gerardo Ávila ${ }^{5}$, Sandra Medina ${ }^{1}$.
}

\begin{abstract}
Worldwide, urban policies are encouraging more compact development in cities arguing environmental sustainability and higher economic productivity. However, there is limited evidence for the relationship between urban form and economic productivity outside high-income countries. While we know that workers in larger cities are more productive, existing empirical evidence on the relationship between compactness and productivity is only from high-income countries, with a productive service sector. Given that the economic base of many cities in Mexico consists of landintensive manufacturing activities, policies promoting urban compactness have potential negative impacts on economic growth by restraining expansion.

In this paper we explore the relationship in time between urban form/spatial structure and economic productivity in Mexico, by testing the hypothesis that growing in a compact way is positively associated with labor productivity. That hypothesis is not completely rejected because several measures of urban form are positively correlated with higher levels of productivity, and other measures are negatively correlated. As the principal findings are counterintuitive, they raise questions about what is the accepted knowledge of urban growth.
\end{abstract}

Keywords: Urban Form; urban structure; productivity; manufacturing; México.

\section{Introduction}

Worldwide, several international development lenders are firmly promoting compactness in cities as one of the major sustainability backbone (i.e. World Bank, InterAmerican Development Bank, etc.). Thus, national and local Latin American governments (seeking for funds) tend to design and apply territorial public policies in this regard, without having a deep understanding on how those policies would affect them in the near future.

Since México and other Latin American Countries (LAC) base their economies mostly on manufacturing, it's reasonable to raise a fundamental question aimed to answer if that empirical relationship stills stand within countries whose cities have different economic base. That question was first raised by Monkkonen in (Kim, Yoonhee \& Zangerling, Bontje, 2016, p. 47):

"[...]Similarly, economic density may not be particularly relevant for manufacturing sector productivity because most of the manufacturing sector

\footnotetext{
| ${ }^{1}$ Centro de Investigación en Ciencias de Información Geoespacial, A.C. (CentroGeo-CONACYT).

2Luskin School of Public Affairs, UCLA.

${ }^{3}$ University of Pennsylvania.

${ }^{4}$ Universidad Panamericana.

5Universidad Autónoma Metropolitana.

*Corresponding Author. CentroGeo-CONACYT. Contoy 137, Col. Lomas de Padierna, Delegación Tlalpan, CP. 14240, México, CDMX. (52) (55) 26152508.
} 
growth and productivity are driven by cost and quality of factors of production such as land, labor, and capital. [...]"

This counterintuitive relationship had not been seen previously although there were studies showing limited benefits to agglomeration in some regions.

At first glance, the relationship might be obvious: since manufacturing is a land consuming activity, it tends to seek exurban and accessible locations for lowering their costs. Therefore, if Mexico's economic base still is manufacturing, and manufacturing locates in the urban fringe, cities with a more disperse and scattered pattern should be more productive in the terms mentioned above. But what's more important is that a) general discourses about compactness and its alleged sustainability benefits should be nuanced and properly targeted; b) there could be potential negative effects if the same urban containment policies are applied to Mexican cities regardless their economic base; and c) more empirical research is needed for having a better understanding which territorial public policy suits developing countries such as Mexico within a sustainability frame as the 2030 UN-habitat goals one.

The remainder of this paper goes as follows. Section 2 highlights urban formproductivity related literature, as well as previous research outcomes completed by this research group. Section 3 broaden over data, methods and strategies followed for improving the models quality. Next section reports findings for the best fitted models. Finally, in Section 5 we explain some outcomes-related handicaps and we propose a few specific territorial policies for Mexico specific case.

\section{What we know so far about urban form (spatial structure) and productivity}

As largely stated previously in Montejano, Monkkonen, Guerra, \& Caudillo (2019) and in Monkkonen et al. (2019), several papers on theories about economic efficiency and urban spatial structure agree upon agglomeration economies increase productivity, but also that there are size limits where agglomeration stop being beneficial for the system and start to generate diseconomies when they exceed certain threshold, like congestion, pollution, etc. (i.e. Camagni, 2005; Duque, Lozano-Gracia, Patino, \& Restrepo, 2019; Glaeser, 2010; O’Sullivan, 2019).

Related to city size and productivity (see Fig. 1), empirical evidence has shown a nonlinear (supra linear) increase in labor productivity when cities sizes doubles, not only in American cities, but amongst OECD cities, ranging between 3-15\% (Ahrend, Farchy, Kaplanis, \& Lembcke, 2014, 2017; Angel \& Blei, 2016; Batty, 2008; Bettencourt, Lobo, Helbing, Kühnert, \& West, 2007; Fogarty \& Garofalo, 1988; Meijers \& Burger, 2010; Prud'homme \& Lee, 1999; Sveikauskas, 1975; West, 2017). Despite negative externalities associated with economies of scale, its seems that "bigger is better" to a certain point if it has to do with increasing economics outputs in the short term, even in Mexico (Ahrend et al., 2014, p. 8; Kim, Yoonhee \& Zangerling, Bontje, 2016, p. 17). A recent Asian work found also that size increase productivity in Chinese cities, meaning they still have room for urban growth, but highlight the specific threshold (the famous inverted "U" shape) where productivity promoted by population concentration begins to decline, marking the moment where government should redistribute population in order to avoid diseconomies of scale (Chen \& Zhou, 2017; Shen, Chen, Yang, \& Zhang, 2019). 
Regardless of this, other recent studies (McCann \& Acs, 2011) challenge the "bigger is better" statement, by saying that most productive cities in the world are the ones who have a population under 3 million inhabitants, followed then by cities up to 7 million, and thus, suggesting mid-sized cities are more productive. Other studies advise that the size-productivity relationship is highly context dependent (Frick \& Rodríguez-Pose, 2018). Clearly, this could depend upon what measure of productivity is used.

Now, from empirical evidence between urban form and productivity, we also know for instance that doubling employment density would increase labor productivity by about 6\% (Ciccone \& Hall, 1996); that more dispersed urban structures (namely sprawled) tend to reduce levels of productivity (Fallah, Partridge, \& Olfert, 2011); that doubling the degree of polycentricity would increase $5.5 \%$ labor productivity (Meijers \& Burger, 2010); and that the more fragmented the territory is (i.e. more districts in a metropolitan area), the less productive due to governance issues (Ahrend et al. 2017). European studies confirm those findings (Combes, Duranton, Gobillon, \& Roux, 2010) although other Asian ones show mixed results (Azari, Kim, Kim, \& Ryu, 2016; Ke, 2010).

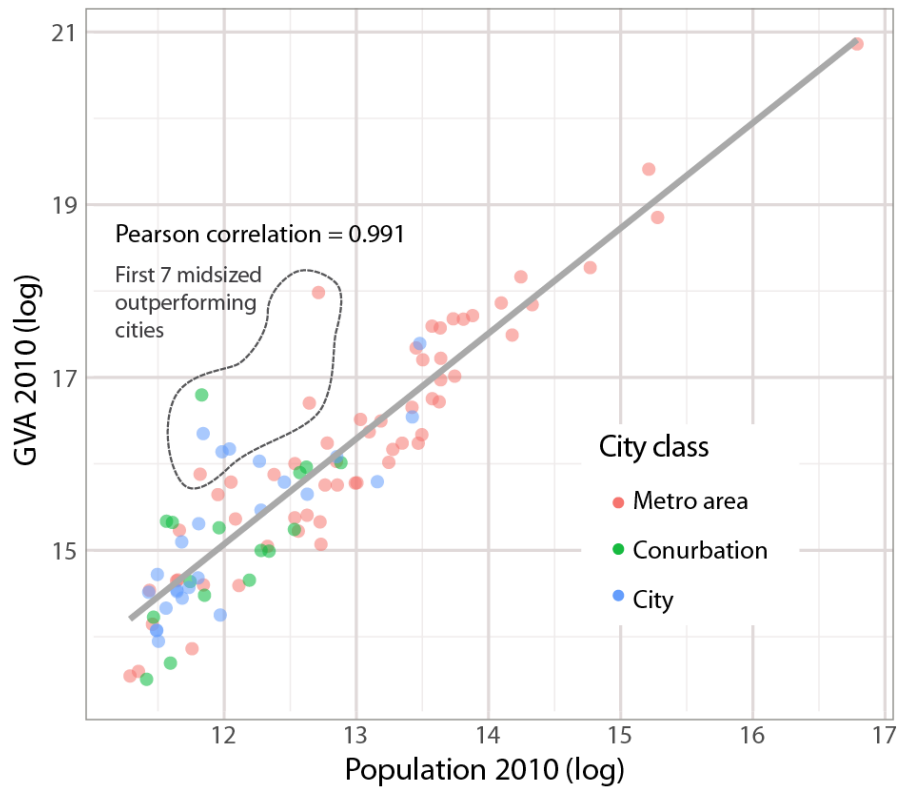

Fig. 1. Log-Log relationship between Gross V alue Added (GVA) and population for the 100 largest Mexican cities. GV A here is the sum of manufacturing, commerce and non-financial services GV A for 2009. If you filter this list by the ten most productive per population cities, we'll shall see that 7 out of ten outperforming cities correspond to small and midsized cities (in ascending order: Coatzacoalcos, San Juan del Rio, Tebuantepec, Monclova-Frontera, Salamanca, Minatitlán, San Luis Potosi). Source: Own with INEGI, 2014 and INEGI, 2010.

In fact, a recent Chinese study found a strong negative relationship between dispersion and labor productivity. In this case, they take this as a sign of polycentricity, which produces agglomeration economies "which in turn could benefit urban productivity" (Li \& Liu, 2018, p. 57). This outcome is probably not surprising, since it is very well known the inverted " $U$ " shape phenomena already mentioned is the base of 
formation of new employment sub centers, most of them, exurban ones (Muñiz, Galindo, \& García, 2005, p. 8). What needs to probably be addressed here is the way outcomes of regressions are theoretically interpreted, because having that strong relationship between dispersion and labor productivity could mean not just only the formation of new sub centers (a polycentric pattern), but the confirmation of more productive territories under sprawling conditions.

Also, it seems that transit accessibility to jobs plays a key role toward increasing productivity (not analyzed in this paper). Recent publications suggest there is a positive and strong relationship between transport investment and GDP, and that accessibility is also positive related to wage earnings (Alotaibi, Quddus, \& Imprialou, 2019; Börjesson, Isacsson, Andersson, \& Anderstig, 2019). This suggests what probably matter most for productivity from a morphological point of view is not the geographical place (distance to center, etc.), but the built environment quality. Hamidi and Zandiatashbar (Hamidi \& Zandiatashbar, 2019) found for a US study, that for raising innovation productivity, firms tend to locate in census tracts that are "less compact but offer spatial proximity to firms in related business sectors" (p. 1). Higher land value in central places seems to have a crucial impact on firm outer locations.

In short, the literature shows that:

- larger urban settlements tend to have a superior productive output due to agglomeration, knowledge spillovers and best accessibility given by the installed infrastructure, but small and midsized cities perform better when productivity is normalized by population

- higher densities in urban spatial structures are often related with more productive economies, in particular those whose economic base are specialized services due to resources optimization

- polycentrism seems to be the next evolving stage for continuing economic growth when monocentric agglomerations reach certain benefit threshold

\subsection{Mexico economic context and its evolution}

Nearly 50 years ago, most of Mexican industry was strongly and spatially concentrated in just four manufacturing subsectors (out of 20) mainly in Mexico City, which used to produce almost half of the overall national gross industrial product; the central region accounted for about twice the GDP per capita compared to other regions (Garza 1980, Unikel, 1978). That hyper-concentration led the Federal Government to promote a large spatial industrial deconcentration seeking for a better regional balance. Between 1980 and 2003, the "concentrated dispersion" of manufacturing effectively took place. There was a boom in the Northern Border states and in the periurban zones of Mexico City region, causing a decrease in Mexico City dominance over manufacturing economy (Dávila, 2004; Mendoza-Cota \& Pérez-Cruz, 2007; Sobrino, 2002; Vieyra, 2000). Nowadays, not just the Northern Border cities had experienced an increase in manufacturing jobs, at the same time manufacturing jobs have been deconcentrated on a metropolitan level, at intra-metropolitan level we observe a general trend of 
manufacturing jobs being relocated to the outskirts of cities, thus, diminishing the concentration on central cities' areas.

Central to this paper is that manufacturing is still the most productive activity in Mexico, near two and a half times more productive than services (see Fig. 3). In this regard, public policies aimed to fulfill accepted urban sustainability criteria should be properly targeted by being aware of the Mexican urban spatial structure reality. Other relevant aspect of the Mexican economy is that the manufacturing sector is the only with a subtle ascending trend in the labor productivity (both services and commerce are declining).

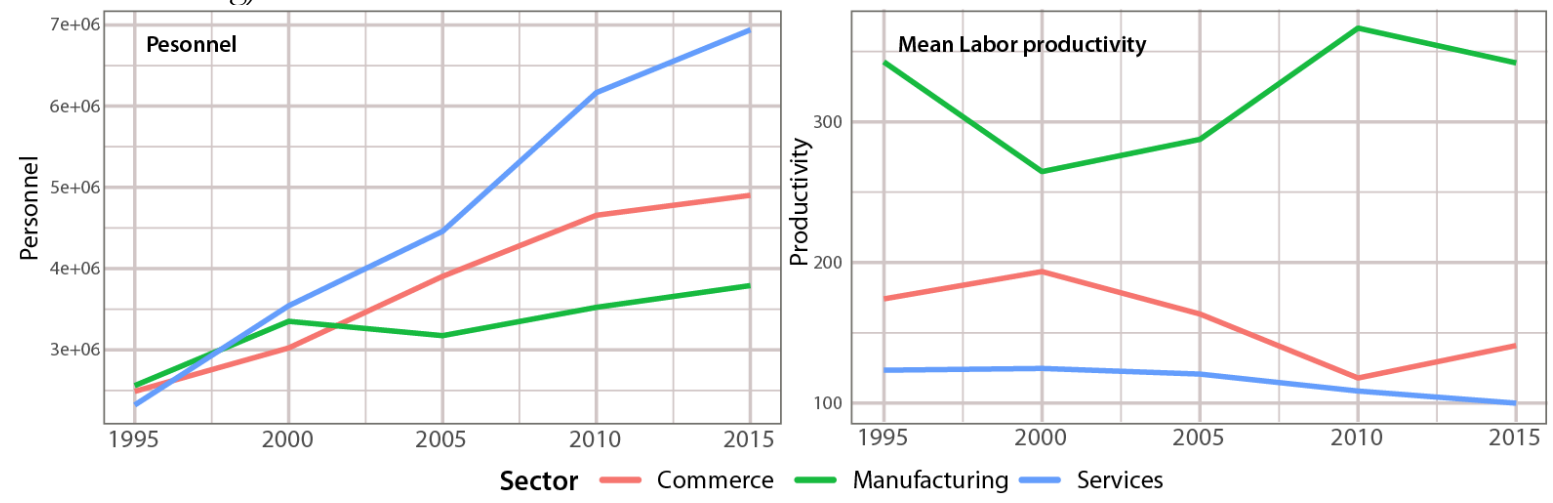

Fig. 2. Personnel employed and Labor Productivity by sector for the NUS 100 largest cities 1993-2013. Images reflects the relevance of this study: while services (less productive) employ more personnel, manufacturing, employing less, is still more productive and the base of Mexican economy. Source: Own with INEGI, 1994, INEGI, 1999, INEGI 2009, INEGI, 2014 (Microdata).

\section{Data, indices, research strategies and methods}

\section{Data}

To be sure of previous findings and in order to extend the time span of the longitudinal study (we added 2015, and removed 1990 to the previous 1990-2010 series), we first fixed INEGI's 1995, 2000, 2005, 2010 and 2015 vector geospatial database at census tract level for the 100 largest NUS cities, since there was spatial mismatch. ${ }^{1}$

For calculating several urban structure measures and economic indices, we worked at the INEGI's microdata Laboratory with the economic censuses for building a panel database (INEGI, 1993, 1998, 2003, 2008, 2013), and public data from the Population Censuses. Data is disaggregated at census tract level (AGEB) and at large sector for Manufacturing, Commerce and Services, using the North American Industry Classification System (NAICS - SCIAN) classification. To estimate productivity, the measure of real gross value added (GVA) per employed personnel was used.

${ }^{1}$ In a previous work (Montejano et al. 2019) we noticed there were some errors in the official digital cartography causing the loss of area of some cities over time, and probably erroneous calculations of urban structure metrics. As a part of the research, we did a land-use classification for the largest 100 NUS cities (Nuñez et al., 2019) into urban and non-urban through remote sensing using high resolution imagery (circa 2015), the main finding is that some metropolitan areas have large manufacturing firms outside of the urban land. 
GVA/employed personnel is considered a good measure to estimate productivity when using primary inputs such as labor.

\section{Indices}

Urban Spatial Metrics

For measuring urban spatial structure, we took some of the most cited robust metrics (spatial and a-spatial) in order to capture different dimensions of the concentration/dispersion phenomena (see Fig. 3 and Appendix A for a description of each metric) and arranged according (Reis, Silva, \& Pinho, 2016). It is well known that urban sprawl is a multi-factorial and complex spatial phenomenon, so it cannot be defined with a single variable (Angel, Parent, \& Civco, 2010b; Ewing, Pendall, \& Chen, 2002).

Table 1. Urban Spatial Structure Metrics.

\begin{tabular}{|c|c|c|}
\hline CATEGORY & METRIC & SOURCE(S) \\
\hline$\underline{\text { Density }}$ & $\begin{array}{l}\text { (1) Population / Job } \\
\text { Density }\end{array}$ & $\begin{array}{l}\text { (Boyko \& Cooper, 2011; } \\
\text { Galster et al., 2001) }\end{array}$ \\
\hline \multirow{2}{*}{ Centrality } & (2) Density Gradient & (Galster et al., 2001) \\
\hline & (3) Centrality Index & (Galster et al., 2001) \\
\hline \multirow{3}{*}{ Compactness } & (4) Proximity Index & $\begin{array}{l}\text { (Angel, Parent, \& Civco, } \\
\text { 2010a) }\end{array}$ \\
\hline & (5) Shape Index & $\begin{array}{r}\text { ( VanDerWal et al, 2019; } \\
\text { Gyenizse et al, 2014; Patton, 1975) }\end{array}$ \\
\hline & (6) Compactness & $\begin{array}{l}\text { (Amindarbari \& Sevtsuk, } \\
\text { 2015) }\end{array}$ \\
\hline Fragmentation & (7) Discontiguity & $\begin{array}{l}\text { (Amindarbari \& Sevtsuk, } \\
\text { 2015) }\end{array}$ \\
\hline \multirow{3}{*}{$\underline{\underline{\text { Evenness of }}}$} & (8) Gini Coefficient & $\begin{array}{l}\text { (Burt, Barber, \& Rigby, } \\
\text { 2009) }\end{array}$ \\
\hline & (9) Clustering Index & $\begin{array}{l}\text { (Pereira, Nadalin, } \\
\text { Monasterio, \& Albuquerque, } \\
\text { 2013) }\end{array}$ \\
\hline & (10) Moran I & (Tsai, 2005) \\
\hline Complexity & (11) Fractal Dimension & $\begin{array}{l}\text { (VanDerWal et al, 2019; } \\
\text { Lovejoy, 1982) }\end{array}$ \\
\hline
\end{tabular}

Economic indices

In order to have a broader understanding of the productivity phenomena and to control the models, we calculate the following five measures also at microdata level: Herfindahl-Hirschman Index (Rhoades, 1993), Diversification Index (Acar \& Sankaran, 1999), Lawrence Index (Sapir, 1996), Krugman Index (Krugman, 2001) and Relative Concentration Index (see Appendix B for a detailed description of each metric). 


\section{Research Strategies and Results}

We adjusted panel linear models ${ }^{2}$ to investigate the association between labor productivity and urban structure with pooled data from 1995, 2000, 2005, 2010 and $2015^{3}$. In a first stage we determine the best suited controls (population and GVA specialization, also the Krugman index works but is correlated with some of the urban structure metrics) and introduced one urban form metric at the time. For both total and manufacturing labor productivity, we found the same variables to be statistically significant. In Appendix B we present a summary statistics table to help the interpretation of the models. Results for models with only one predictor available under request.

As urban form is a complex concept to measure, we combined some independent urban form/structure metrics in several models. The models presented in figure 4 are only for manufacturing labor productivity (general productivity models can be seen on Appendix C). The dependent variable is the average productivity per worker in a given city. Putting aside the controls (the main factors driving the city's productivity, see model 1 as baseline), we find some significant associations with urban form metrics. Models 2 to 4 includes the spatial autocorrelation index Moran's I for manufacturing jobs with negative sign - the interpretation of high values are a tendency to monocentric employment structure, low to negative values are associated with a more polycentric structure -, this association implies the more monocentric is the industrial jobs spatial pattern, the less productive the city is. In Model 2 Fragmentation Index (discontiguity) is significative with a negative sign, indicating that leap frog development (more fragmentation) is associated with less productivity. This metric has a monotonic ascending trend. In other words, all the cities show a steady way to sprawl. The second best model (3) incorporates the Population Density Gradient with negative sign. This could mean that the more central the density is (also a proxy of compactness) the less productive is a city. In Model 4 we added the Gini Index of the population - the index measures concentration of the population in surface, but is insensitive of the spatial pattern- The sign indicates a positive association between population concentration and productivity (after controlling for city size, specialization and spatial pattern of industrial jobs).

2 Our panel have 500 observations (100 cities and 5 times). We fitted the models with both fixed and random effects estimators, then selected the fixed effects models after testing for consistency. All the models incorporated time effects. The urban form metrics characterize the patterns of Population (Pop), Total Personnel (Per) and Manufacturing personnel (Man) distribution in the urban space. Fragmentation (discontiguity), Fractal Dimension and Shape Index characterize solely the shape of the urban footprint.

${ }^{3}$ For the following of the demographic indicators for 2015, INEGI issued a intercensus survey. So, in order to obtain the intraurban population at the census tracts level, we fitted OLS models of population predicted by occupied housing units and distance from CBD from the 2010 census data and then estimate the population for 2015 with the last update of the National Housing Inventory (INEGI 2016), the $\mathrm{R}^{2}$ obtained in the model was 0.981 . 
Table 2. Panel regression results for manufacturing labor productivity.

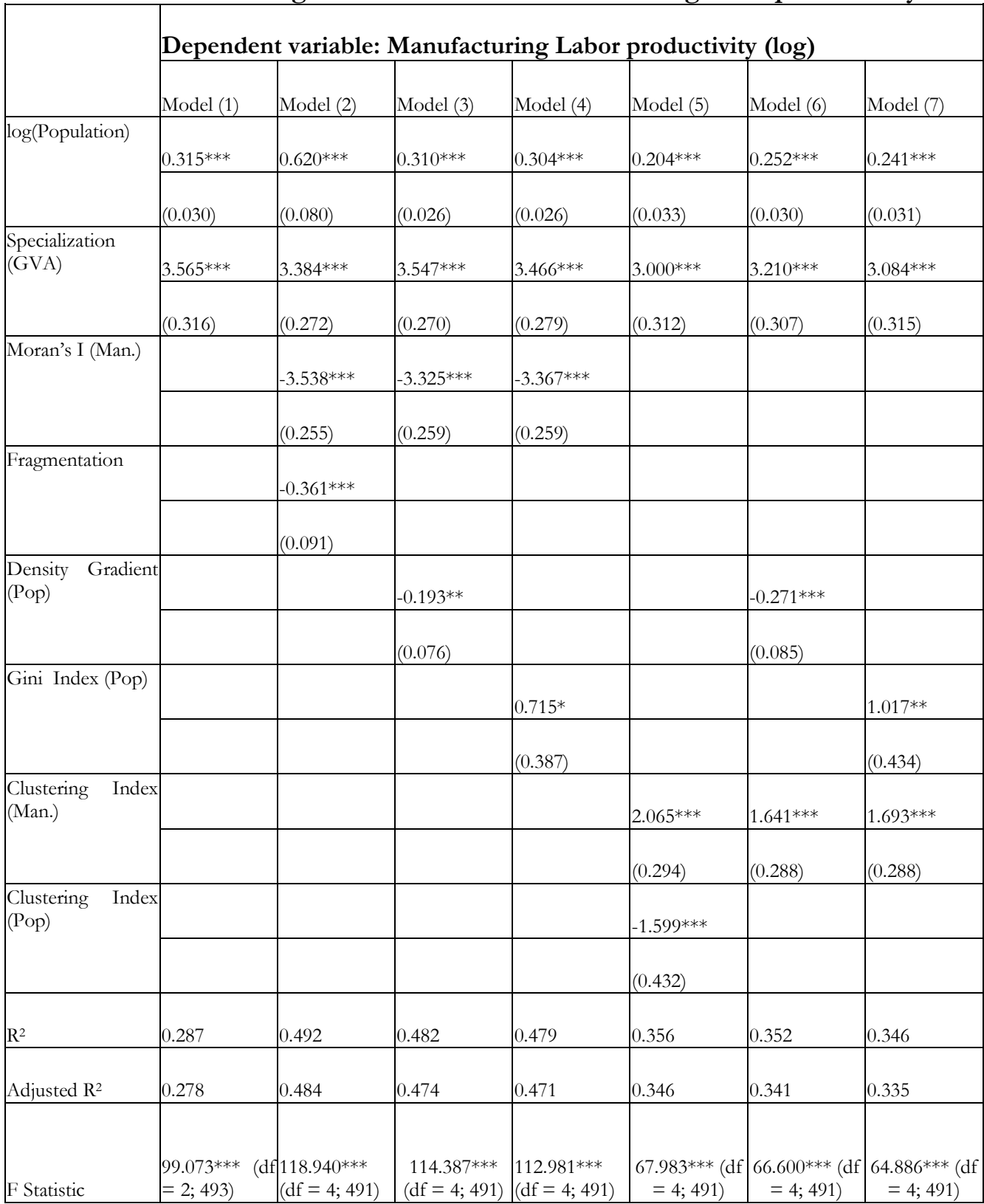

The next three models (5 to 7 ) incorporates the Manufacturing Jobs Clustering Index (similar to Gini, but in its calculation the surface is replaced by the number of census tracts) with positive sign, indicating the more concentrated in few census tracts are the industrial jobs the more productive are the cities. This could be contradictory with the previous findings. Nevertheless, we need to keep in mind that this index is not 
sensitive to the spatial distribution of jobs, so high clustering could be consistent with both a monocentric and a polycentric structure. The Clustering Index of Population is also significant in model 5 , but with negative sign, indicating the more concentrated is the population the less productive the city. Model 6 also includes the Density Gradient of Population with negative sign, in other words, the more central is the population density the less productive is the city. Our last model incorporates the Gini Index of Population with positive sign. This implies that concentration of population in less census tracts is associated with more productivity.

\section{Conclusions}

In purely economic terms, we can agree with Marshall's theories that establish specialization is one of the leading forces of the economy. In all of our models, we find positive and strong correlations between the Herfindhal-Hirshman Index and manufacturing productivity. Also the city size seems to be important. At some extent, the scale economies are working, and there is strong evidence that there is a real potential for improving productivity by focusing on mid-sized cities of the NUS, where probably diseconomies do not manifest themselves as strong as they do in mega cities.

One aspect beyond the merely economic point of view is the sustainability of urban development, a central concern in our research. We now have evidence of a 'dense sprawl' in Mexican cities; the Fragmentation Index is growing over time and the Density Gradient of both population and jobs have a general tendency to lower values meaning a totally different growth pattern compared to U. S. cities- So, in sustainability terms, the trend towards a leap frog development can be seen as a negative consequence of urban development, but there is also evidence that this could be just a stage in a successive expansion and filling phases. In the context of the largest 100 Mexican cities, the behavior of the urban structure metrics raises concerns regarding this particular form of sprawl, that can be seen a symptom of a serious lack of urban planning.

In terms of economic output, the manufacturing productivity in the 100 largest Mexican cities shows only a gentle upward trend. Nevertheless, is a very important sector of the economy and also carries territorial impacts. In several cities, there is a steady trend to locate industry in the outskirts, where land is cheap and Mexican local governments offers economic incentives for that geographic location. As this can be a driver for exurbanization, there is a potential conflict due to a poor accessibility context of and a general low quality services context. As there is no a particular housing policy that support efficiently this exurban manufacturing location, general housing policy haven't achieve in providing affordable and accessible homes for all of the dependent economic sectors (commerce, services, manufacturing), creating a double burden on the poor households in the urban periphery: neither factories workers nor services blue collar employees have good accessibility to their working centers and thus, its peripheral location plays a key role on lowering their life quality.

In our models we have mixed evidence regarding the relationship between urban form and productivity. In the one hand, we found that the spatial pattern of manufacturing jobs is the most important UF metric, meaning that dispersing the 
industry in the metropolitan fabric is positively correlated with labor productivity, but in the other hand, urban footprint fragmentation has a negative correlation. If we add the Moran's I and Clustering Index variable, we could probably hypothesize that we are in front of a more productive industry, located in a "concentrated-dispersion" manner. This resembles polycentrism and we need to dig deeper on that relationship.

In terms of public policy, we urge policymakers to broaden their vision regarding territorial arrangements. In the same way that services and retail are more productive when they are concentrated within the urban fabric, probably manufacturing is more productive under a polycentric and "concentrated-dispersion" layout. So the fact that all cities should have the same 'compact city' territorial policy could not be the best way to guide territorial decisions while industry have different efficiency logics. Thus, there should be a differentiated planning goals depending on the geographical context and economic base that embrace the benefits of dispersion and incorporates accessibility as the main axis.

The authors thank the anonymous reviewers for their comments and suggestions. We also thank the financial support granted by the Fondo Sectorial INEGICONACYT (278953-S0025-2016-1) project.

\section{References}

Acar, W., \& Sankaran, K. (1999). The myth of the unique decomposability: Specializing the Herfindahl and entropy measures? Strategic Management Journal, 20(10), 969-975.

Ahrend, R., Farchy, E., Kaplanis, I., \& Lembcke, A. C. (2014). What Makes Cities More Productive? Evidence on the Role of Urban Governance from Five OECD Countries [OECD Regional Development Working Papers].

Ahrend, R., Farchy, E., Kaplanis, I., \& Lembcke, A. C. (2017). What makes cities more productive? Evidence from five OECD countries on the role of urban governance. Journal of Regional Science, 57(3), 385410.

Alotaibi, S., Quddus, M., \& Imprialou, M. (2019). Quantifying the Relationship Between Transport Investment and Productivity in the Kingdom of Saudi Arabia. Presentado en Transportation Research Board 98th Annual Meeting'Transportation Research Board.

Amindarbari, R., \& Sevtsuk, A. (2015). Metropolitan Form Analysis Toolbox for ArcGIS v 10.2 and v 10.3.1.

Angel, S., \& Blei, A. M. (2016). The productivity of American cities: How densification, relocation, and greater mobility sustain the productive advantage of larger U.S. metropolitan labor markets. Cities, 51, 36-51. https://doi.org/10.1016/j.cities.2015.11.030

Angel, S., Parent, J., \& Civco, D. L. (2010a). Ten compactness properties of circles: Measuring shape in geography. The Canadian Geographer/Le Géographe canadien, 54(4), 441-461.

Angel, S., Parent, J., \& Civco, D. L. (2010b). The Fragmentation of Urban Footprints: Global Evidence of Sprawl, 1990-2000. Lincoln Institute of Land Policy, Cambridge, US A.

Azari, M., Kim, H., Kim, J. Y., \& Ryu, D. (2016). The effect of agglomeration on the productivity of urban manufacturing sectors in a leading emerging economy. Economic Systems. https://doi.org/doi:10.1016/j.ecosys.2015.08.005

Batty, M. (2008). The size, scale, and shape of cities. science, 319(5864), 769-771.

Bertaud, A., \& Malpezzi, S. (1999). The spatial distribution of population in 35 World Cities: The role of markets, planning and topograpby [Working Paper]. Chevy Chase, MD: The Center for urban land and economic research, The University of Wisconsin.

Bettencourt, L. M. A., Lobo, J., Helbing, D., Kühnert, C., \& West, G. B. (2007). Growth, innovation, scaling, and the pace of life in cities. Proceedings of the National Academy of Sciences, 104(17), 7301-7306. https://doi.org/10.1073/pnas.0610172104 
Börjesson, M., Isacsson, G., Andersson, M., \& Anderstig, C. (2019). Agglomeration, productivity and the role of transport system improvements. Economics of Transportation, 18, 27-39. https://doi.org/10.1016/i.ecotra.2018.12.002

Boyko, C. T., \& Cooper, R. (2011). Clarifying and re-conceptualising density. Progress in Planning, 76(1), 1-61.

Burt, J. E., Barber, G. M., \& Rigby, D. L. (2009). Elementary statistics for geographers (3th ed.). New York, London: The Guilford Press.

Camagni, R. (2005). Economia urbana. Barcelona: Antoni Bosch. /z-wcorg/.

Chen, J., \& Zhou, Q. (2017). City size and urban labor productivity in China: New evidence from spatial city-level panel data analysis. Economic Systems, 41(2), 165-178. https://doi.org/10.1016/i.ecosys.2016.07.002

Ciccone, A., \& Hall, R. E. (1996). Productivity and the Density of Economic Activity. American Economic Review, 86(1), 54-70.

Combes, P.-P., Duranton, G., Gobillon, L., \& Roux, S. (2010). Estimating agglomeration economies with history, geology, and worker effects. En Agglomeration Economics (pp. 15-66). University of Chicago Press.

Dávila, A. D. (2004). México: Concentración y localización del empleo manufacturero, 1980-1998. Economía Mexicana Nueva época, 13(2), 209-254.

Duque, J. C., Lozano-Gracia, N., Patino, J. E., \& Restrepo, P. (2019). Urban Form and Productivity: What Is the Shape of Latin American Cities? The World Bank.

Ewing, R., Pendall, R., \& Chen, D. D. T. (2002). Measuring sprawl and its impact. Washington, D.C.: Smart Growth America.

Fallah, B. N., Partridge, M. D., \& Olfert, M. R. (2011). Urban sprawl and productivity: Evidence from US metropolitan areas. Papers in Regional Science, 90(3), 451-472.

Fogarty, M. S., \& Garofalo, G. A. (1988). Urban spatial structure and productivity growth in the manufacturing sector of cities. Journal of Urban Economics, 23(1), 60-70.

Frick, S. A., \& Rodríguez-Pose, A. (2018). Big or Small Cities? On city size and economic growth. Growth and Change, 49(1), 4-32. https://doi.org/10.1111/grow.12232

Galster, G., Hanson, R., Ratcliffe, M. R., Wolman, H., Coleman, S., \& Freihage, J. (2001). Wrestling sprawl to the ground: Defining and measuring an elusive concept. Housing policy debate, 12(4), 681-717.

Garza, G. (1980). Industrialización de las principales cindades de México: Hacia una estrategia espacio-sectorial de descentralización industrial. México: El Colegio de México.

Glaeser, E. L. (2010). Agglomeration economics. Recuperado de http://public.eblib.com/choice/publicfullrecord.aspx?p $=515742$

Gyenizse, P., Bognár, Z., Czigány, S., \& ELekes, T. (2014). Landscape shape index, as a potential indicator of urban development in Hungary. Acta Geographica Debrecina. Landscape and Environment Series, 8(2), $78-88$.

Hamidi, S., \& Zandiatashbar, A. (2019). Does urban form matter for innovation productivity? A national multi-level study of the association between neighbourhood innovation capacity and urban sprawl. Urban Studies, 56(8), 1576-1594. https://doi.org/10.1177/0042098018767002

INEGI. (1993). Censos Económicos 1994, microdatos. Recuperado de Instituto Nacional de Estadística y Geografía website: https://www.inegi.org.mx/programas/ce/2014/

INEGI. (1998). Censos Económicos 1999, microdatos. Recuperado de Instituto Nacional de Estadística y Geografía website: https://www.inegi.org.mx/programas/ce/2009/

INEGI. (2003). Censos Económicos 2004, microdatos. Recuperado de Instituto Nacional de Estadística y Geografía website: https://www.inegi.org.mx/programas/ce/1999/

INEGI. (2008). Censos Económicos 2009, microdatos. Recuperado de Instituto Nacional de Estadística y Geografía website: www.inegi.gob.mx

INEGI. (2013). Censos Económicos 2014, microdatos. Recuperado de Instituto Nacional de Estadística y Geografía website: www.inegi.gob.mx

Ke, S. (2010). Agglomeration, productivity, and spatial spillovers across Chinese cities. The annals of regional science, 45(1), 157-179.

Kim, Yoonhee, \& Zangerling, Bontje (Eds.). (2016). Mexico Urbanization Review. Washington, D.C.: World Bank Group.

Krugman, P. (2001). Lessons of Massachusetts for EMU'. International Library of Critical Writings in Economics, 134(41-61). 
Li, Y., \& Liu, X. (2018). How did urban polycentricity and dispersion affect economic productivity? A case study of 306 Chinese cities. Landscape and Urban Planning, 173, 51-59. https://doi.org/10.1016/i.landurbplan.2018.01.007

Lovejoy, S. (1982). Area-Perimeter Relation for Rain and Cloud Areas. Science, 216(4542), 185-187. https://doi.org/10.1126/science.216.4542.185

Mandelbrot, B. (1967). How Long Is the Coast of Britain? Statistical Self-Similarity and Fractional Dimension. Science, New Series, 156(3775), 636-638.

Malpezzi, S., \& Guo, W.-K. (2001). Measuring "sprawl": Alternative measures of urban form in US metropolitan areas [Unpublished manuscript]. Madison, WI: Center for Urban Land Economics Research, University of Wisconsin.

McCann, P., \& Acs, Z. J. (2011). Globalization: Countries, cities and multinationals. Regional Studies, 45(1), $17-32$.

Meijers, E. J., \& Burger, M. J. (2010). Spatial structure and productivity in US metropolitan areas. Environment and planning $A, 42(6), 1383-1402$.

Mendoza-Cota, J. E., \& Pérez-Cruz, J. A. (2007). Aglomeración, encadenamientos industriales y cambios en la localización manufacturera en México. Economía Sociedad y Territorio, VI(23), 655-691.

Monkkonen, P., Montejano, J., Guerra, E., \& Caudillo, C. (2019). Compact Cities and Economic Productivity in Mexico. Urban Studies, under Production for copyediting and typesetting.

Montejano, J., Monkkonen, P., Guerra, E., \& Caudillo, C. (2019). The costs and benefits of urban expansion: Evidence from Mexico, 1990-2010. Lincoln Institute of Land Policy.

Muñiz, I., Galindo, A., \& García, M. Á. (2005). Descentralización, integración y policentrismo en Barcelona. Recuperado de http://hdl.handle.net/2072/2117

Núñez, J. M., Medina, S., Ávila, G., \& Montejano, J. (2019). High-Resolution Satellite Imagery Classification for Urban Form Detection. In Satellite Information Classification and Interpretation. IntechOpen.

O’Sullivan, A. (2019). Urban economics. New York, NY: McGraw-Hill/Irwin.

Patton, D. R. (1975). A Diversity Index for Quantifying Habitat "Edge". Wildlife Society Bulletin, 3(4), 171173. https://doi.org/10.2307/3781151

Pereira, R. H. M., Nadalin, V., Monasterio, L., \& Albuquerque, P. H. (2013). Urban centrality: A simple index. Geographical analysis, 45(1), 77-89.

Prud'homme, R., \& Lee, C.-W. (1999). Size, sprawl, speed and the efficiency of cities. Urban Studies, 36(11), 1849-1858.

Reis, J. P., Silva, E. A., \& Pinho, P. (2016). Spatial metrics to study urban patterns in growing and shrinking cities. Urban Geography, 37(2), 246-271.

Rhoades, S. A. (1993). The herfindahl-hirschman index. Fed. Res. Bull., 79, 188.

Sapir, A. (1996). The effects of Europe's internal market program on production and trade: A first assessment. Weltwirtschaftliches Archiv, 132, 457-475.

Shen, J., Chen, C., Yang, M., \& Zhang, K. (2019). City Size, Population Concentration and Productivity: Evidence from China. China \& World Economy, 27(1), 110-131.

Sobrino, L. J. (2002). Globalización, crecimiento manufacturero y cambio en la localización industrial en México. Estudios demográficos y urbanos, 5-38.

Sveikauskas, L. (1975). The productivity of cities. The Quarterly Journal of Economics, 89(3), 393-413.

Tsai, Y.-H. (2005). Quantifying urban form: Compactness versus' sprawl'. Urban studies, 42(1), 141-161.

Unikel, L. S (1976). El desarrollo urbano de México. Diagnóstico e implicaciones. El Colegio de México. Ciudad de México.

VanDerWaal, J., Falconi, L., Januchowski, S., Shoo, L. \& Storlie, C. (2019) SDMTools: Tools for processing data associated with species distribution modelling exercises (Version 1.1-221.1)[R package].

Vieyra, J. A. (2000). Reconversión industrial, gran empresa y efectos territoriales: El caso del sector automotriz en México. EURE (Santiago), 26(77), 25-47.

West, G. B. (2017). Scale: The universal laws of growth, innovation, sustainability, and the pace of life in organisms, cities, economies, and companies. Penguin. 
Appendix A. Urban Spatial Structure Metrics (excerpts from Montejano et al., 2019, p. 18-22).

Density: Density is perhaps the most common and simple measure of urban structure. It is simply the number of units or events found in a given area (Boyko \& Cooper, 2011). Depending on the scale and scope, it can measure population, jobs, or dwelling unit density.

Density Gradient: The Density Gradient is the simplest measure of an urban areas central tendency. It is the rate at which density falls at larger distances from the city center. Density is generally highest in the city center, and the rate of decrease is exponential moving outward in most cities (Clifton, Ewing, Knaap \& Song, 2008). First developed by Clark in 1951 and later used by Mills (1972), it has often been used to test the monocentricity of a city's form.

Centrality Index: The Centrality Index (Galster et al. 2001) measures the degree to which urban features are closely located near the CBD. Lower levels of centralization indicate a higher level of sprawl. The main difference between this index and the density gradient is that this tool does not measure decay. It is calculated by adding up the inverse distance of each census tract, weighted by its population. Then, the 'average distance' is standardized by the city's size in question, dividing it by the squared root of the total urban area.

Proximity Index: This index was developed by Angel and colleagues (2010a) to assess urban compactness. It is the 'ratio of the average distance from all points in the equal-area circle to its center and the average distance to the city center from all point in the city footprint' (Angel, Parent, and Civco 2010a, 11). It assumes that the circle is the most compact shape, theoretically ranges from 0 -indicating a linear city - to 1 - a perfect circle-, this index only accounts for the shape of the urban footprint.

Compactness: Proposed by Amindarbari and Sevtsuk (2015) is defined as 'the degree to which the resources of a city -people, buildings, jobs, etc.- are spatially scattered: the closer to each other are located, the more compact the city is. The index relies on a gravity model, to grasp the accessibility degree from different parts of the city to each other. In other words, the more accessible different locations are within a city, the more compact it is. The index can be normalized by population, geographical constrains (by subtracting non buildable area) or by the density of the reference city. Once normalized, it could be used for comparing compactness among different cities, the higher the index, the more compact the city.

Discontiguity: We found several fragmentation indices, nevertheless, Amindarbari and Sevtsuk's (2015) Discontiguity (DC) measure the most straightforward. The objective is to characterize the extent to which urban areas develops by leapfrogs- . The DC measures the degree in which urban areas grew without spatial contiguity. The lower the outcome of discontiguity measure, the less fragmented the urban area, this is another of the indices measuring 'pure shape'.

Gini Coefficient: The Gini Coefficient is measure of inequality, and can also be applied to the distribution of population or employment across the different spatial units in a city (Burt, Barber, and Rigby 2009). It has been used as a sprawl index, though it is unclear theoretically whether a more or less equal distribution would be considered sprawling (Tsai 2005). But as it lacks of spatial dimension. Values close to 1 mean population, jobs or dwelling density is very high in just some sub areas, whether values near to 0 would reflect an equally distribution in a city.

Clustering Index: Developed by Pereira et al. (2013) measures the uneven distribution of population, jobs, or housing across a city. It is similar to Gini Coefficient, instead of area, it uses census tracts as the observation unit. Lower values of this index means people or jobs are more homogeneously distributed across the city, and higher values indicates people or jobs are concentrated. 
Moran's I: Measures spatial dependence, is a global spatial autocorrelation index, also measures whether tracts with high values of a variable are clustered, dispersed, or randomly distributed. Moran's I vales are expected to be high, medium and low for monocentric, polycentric, and a decentralized sprawling urban structure. The partial conclusions of Tsai (2005) were that this index could effectively characterize compactness/sprawl alone, but recommends it be used with the Gini Coefficient. The Moran's I does is not sensitive to polycentric or leapfrog development.

Shape Index: This index is commonly used in landscape ecology, was introduced to indicate the divergence of the shape of a landscape patch form the circle (the ideal compact form), Gyenuzse et al. (2014) applied this metric as indicator of urban development. The numerator is the perimeter of the shape of interest, and the denominator is the theoretical area of a circle with the same area of the shape of interest, the greater the index, the less compact the shape.

Fractal Dimension: There are several versions of fractal dimension measures, in this case we computed the proposed by Vandelwal et al. (2019), which is a simplification of the early work of Mandelbrot (1977) and Lovejoy (1982). The index is interpreted as follows: greater values are indicator of more complex shape. This version is simply the ratio between two times the natural $\log$ of the perimeter and the natural $\log$ of the area. The larger the fractal dimension the more complex is the shape of the urban foot print. 


\section{Appendix B Economic Metrics}

Productive specialization: Hirshmann-Herfindahl index (HH):

$$
H H=\sum_{1}^{k}\left(s_{i}\right)^{2}
$$

Where $s_{i}$ is the share of employment in sector $\mathrm{i}$ in the region. $\mathrm{HH}$ is the sum of squares of the shares of its $\mathrm{k}$ industries. Their values range from $1 / \mathrm{k}$ for equal distribution of employment to 1 for concentration of employment in a sector.

Diversification Index. The diversification index is the $\mathrm{HH}$ complement.

$$
D I V=1-H H
$$

Where $s_{i}$ is the share of employment in sector $\mathrm{i}$ in the region. Values range from 0 to 1 , if close the unit indicates high productive diversity.

Lawrence Index. Measures how regional specialization changes over time.

$$
\text { Lawrence }=\frac{1}{2} \sum_{i=1}^{k}\left|s_{i}^{t}-s_{i}^{t-1}\right|
$$

Where $s_{i}$ is the share of employment in sector $\mathrm{i}$ in the region. Values close to 1 indicates change in specialization, close to zero means stability.

Krugman Index. The dissimilarity index, measures the degree of dissimilarity of the sector of specialization of a region in relation to a reference area, generally the country.

$$
D I S S=\sum_{i=1}^{k}\left|s_{i r}-s_{i n}\right|
$$

It has values from 0 to 2 , close to 0 , the dissimilarity is small and the regional specialization is similar to the national one, close to 2 is the opposite.

\section{Relative Concentration Index}

$$
\frac{1}{2} \sum_{j}\left|\frac{L k j}{L k}-\frac{L j}{L}\right|
$$

Where $\mathrm{k}$ is the sector and $\mathrm{j}$ the city. $L k j$ is the employment in sector $\mathrm{k}$ of the city $\mathrm{j}$. Lk is the national employment in the sector $\mathrm{k} . \mathrm{Lj}$ is the total employment in the city $\mathrm{j}$ and $\mathrm{L}$ is the total national employment. The sector is relatively concentrated when the RCI approaches to one and relatively dispersed when approaching to zero. 


\section{Appendix C}

Descriptive statistics table.

Summary statistics of analyzed variables

\begin{tabular}{|c|c|c|c|c|c|}
\hline & & & & & \\
\hline Group/Variable & in & edian & ax & ean & $d$ \\
\hline
\end{tabular}

\section{Dependent variable}

Total Productivity (log)

.08

5.

\begin{tabular}{|c|c|c|c|c|c|}
\hline Total Productivity (log) & .08 & $\begin{array}{r}095 \\
5 .\end{array}$ & i & .136 & .475 \\
\hline Manufacturing productivity (log) & .584 & 287 & .612 & .395 & .783 \\
\hline \multicolumn{6}{|l|}{ Controls } \\
\hline Population (log) & 1.01 & $\begin{array}{r}1 \\
2.409 \\
0 .\end{array}$ & $\begin{array}{r}6.805 \\
\text { । }\end{array}$ & 2.52 & .017 \\
\hline Specialization (GVA) & .333 & 416 & .919 & .445 & .097 \\
\hline \multicolumn{6}{|l|}{ Urban form (Population) } \\
\hline Density Gradient & 0.454 & $\begin{array}{r}0 . \\
455 \\
2 .\end{array}$ & .527 & .499 & .342 \\
\hline Centrality Index & .532 & $\begin{array}{r}197 \\
0 .\end{array}$ & । & .107 & .655 \\
\hline Clustering Index & .166 & $\begin{array}{r}317 \\
0 .\end{array}$ & ( & .335 & .08 \\
\hline Gini Index & .184 & $\begin{array}{r}361 \\
0 .\end{array}$ & $\begin{array}{r}.702 \\
\text { । }\end{array}$ & .363 & .071 \\
\hline Moran's I & 0.097 & 261 & .664 & .261 & 131 \\
\hline
\end{tabular}

\section{Urban form (Personnel)}

Density Gradient

0.412

1.

Centrality Index

097

Clustering Index

.376

Gini Index

2.

.131

Gini Index

.007

948

948

0.

Moran's I

577

577

524

0.

\section{Urban form (Manufacturing Personnel)}

Density Gradient

Centrality Index

Clustering Index

Gini Index

$\begin{array}{rrcrr} & 0 . & \vdots & & \\ 0.707 & 666 & .224 & .704 & .423 \\ .3 & 2 . & \vdots & & \\ & 336 & .743 & .336 & .813 \\ .364 & 0 . & 1 & & \\ & 644 & .897 & .654 & .106 \\ .304 & 0 . & 1 & & \\ & 6 & .834 & .596 & .106\end{array}$


Moran's I

0.084

0.

\section{Urban form (Urban footprint measures)}

Discontiguity $(\log )$

.876

3.

Fractal Dimension

.781

613

2.

$213 \quad .834$

.231 .193 